\title{
Photograph of the month
}

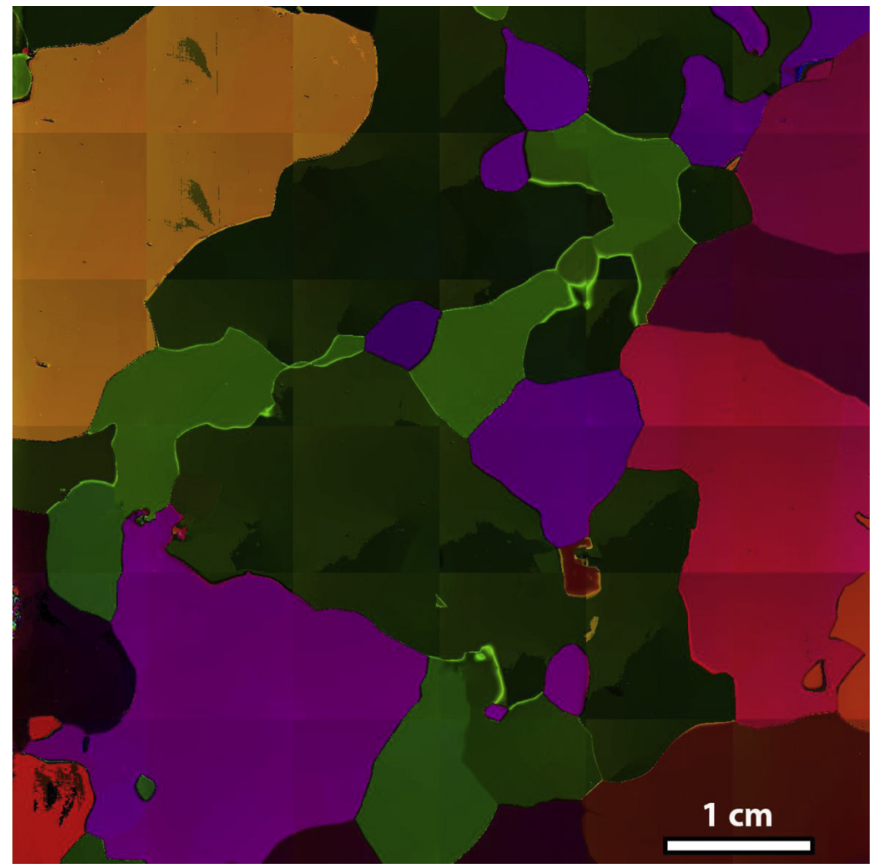

Microstructure of deep polar ice. The image shows ice from the lower, warm part of the EPICA-Dronning Maud Land (EDML) core in the Antarctic ice sheet. At a depth of $2375 \mathrm{~m}$, the ca. 130.000 years old ice is at $-13{ }^{\circ} \mathrm{C}$ (Ruth et al., 2007; Wilhelms et al., 2007), i.e. a homologous temperature of 0.952 . Polar ice is thus a "hot material" with microstructural behaviour close to that of silicate minerals at high metamorphic grades. The image shows the c-axes distribution map (AVA) measured with the automatic fabric analyzer (G50) by Russell-Head Instruments (www.russellheadinstruments.com) (see also Wilson et al. 2014; Peternell et al. 2014; Faria et al., 2014a). Colour coding is according to c-axis orientation. Strong dynamic recrystallization is indicated by interlocking grains and orientation families: the bright purple grains may belong to a single grain with a highly irregular shape, making it appear as multiple grains due to sectioning effects (Urai et al., 1986). The important role of dynamic recrystallization in all depths of the polar ice sheets (homologous temperatures at the cold surface ca. 0.8) lead to the development of the new recrystallization diagram presented in this issue (Faria et al. 2014b). The image is a collage of 36 individual orientation maps. Photograph: Ilka Weikusat \& Sepp Kipfstuhl, Glaciology, Tübingen University \& Alfred-Wegener-Institut Helmholtzzentrum für Polar- und Meeresforschung, Am Alten Hafen 26, 27568 Bremerhaven, Germany. ilka.weikusat@uni-tuebingen. de.

\section{References}

Faria, S.H., Weikusat, I., Azuma, N., 2014a. The microstructure of polar ice. Part I: Highlights from ice core research. Journal of Structural Geology 61, 2-20.

Faria, S.H., Weikusat, I., Azuma, N., 2014b. The microstructure of polar ice. Part II: State of the art. Journal of Structural Geology 61, 21-49.

Peternell, M., Dierckx, M., Wilson, C.J.L., Piazolo, S., 2014. Quantification of the microstructural evolution of polycrystalline fabrics using FAME: Application to in situ deformation of ice. Journal of Structural Geology 61, 109-122.

Ruth, U., Barnola, J.M., Beer, J., Bigler, M., Blunier, T., Castellano, E., Fischer, H., Fundel, F., Huybrechts, P., Kaufmann, P., Kipfstuhl, S., Lambrecht, A. Morganti, A., Oerter, H., Parrenin, F., Rybak, O., Severi, M., Udisti, R. Wilhelms, F., Wolff, E., 2007. EDML1: a chronology for the EPICA deep ice core from Dronning Maud Land, Antarctica, over the last 150000 years. Clim. Past. 3, 475-484. http://dx.doi.org/10.5194/cp-3-475-2007.

Urai, J.L., Means, W.D., Lister, G.S., 1986. Dynamic recrystallization of minerals. Am. Geophys. Un. Monogr. 36, 161-199.

Wilhelms, F., Sheldon, S.G., Hamann, I., Kipfstuhl, S., Kuhs, W.F. (Eds.), 2007. Implications for and Findings from Deep Ice Core Drillings - an Example: The Ultimate Tensile Strength of Ice at High Strain Rates. Physics and Chemistry of Ice, pp. 635-639.

Wilson, C.J.L., Peternell, M., Piazolo, S., Luzin, V., 2014. Microstructure and fabric development in ice: Lessons learned from in situ experiments and implications for understanding rock evolution. Journal of Structural Geology 61, 50-77.

Ilka Weikusat

Tübingen University \& Alfred-Wegener-Institut Helmholtzzentrum für Polar- und Meeresforschung, Am Alten Hafen 26, 27568 Bremerhaven,

Germany

E-mail address: ilka.weikusat@awi.de.

Available online 24 January 2014 